\title{
High-Sensitivity C-Reactive Protein in Subjects with Type 2 Diabetes Mellitus and/or High Blood Pressure
}

\section{artigo original}

\author{
LUCIANA M. LIMA \\ Maria das Grachas Carvalho \\ ANNA L. SOARES \\ ADRIANO DE P. SABINO \\ ANA P. FERNANDES \\ BETHÂNIA A. NOVELLI \\ MARINEZ O. SOUSA
}

Faculty of Pharmacy, Federal University of Minas Gerais (LML,

MGC, ALS, APS, APF \& MOS), and Santa Casa de Misericórdia Hospital (BAN), Belo Horizonte, MG.

Recebido em 18/07/06 Revisado em 09/01/07 Aceito em 23/01/07

\section{ABSTRACT}

Type 2 diabetes mellitus (DM2) and high blood pressure (HBP) may contribute to the development of cardiovascular disease, and inflammation may be an important factor in these diseases. In the present study, plasma levels of high-sensitivity $\mathrm{C}$-reactive protein (hs-CRP) were measured in subjects with DM2 and/or HBP and compared to those of normal subjects. Eighty-nine subjects were analyzed for hs-CRP, including 13 normotensive patients with DM2, 17 patients with HBP, 34 hypertensive patients with DM2 (DM2+HBP) and 25 normal subjects. The plasma hs-CRP levels were significantly lower in the controls than in the HBP+DM2 group $(p<0.05)$. DM2 associated with HBP was also correlated with increased plasma hsCRP levels ( $n=89, r=0.25, p=0.0162$ ). Only hypertensive patients with DM2 had higher levels of hs-CRP, a circulating inflammatory marker, than normal subjects. This finding suggests that patients with two associated diseases have a more active inflammatory state. (Arq Bras Endocrinol Metab 2007;51/6:956-960)

Keywords: High-sensitivity C-reactive protein; Type 2 diabetes mellitus; High blood pressure

\section{RESUMO}

Proteína C-Reativa Ultra-Sensível em Pacientes com Diabetes Mellitus Tipo 2 e/ou Hipertensão Arterial.

Diabetes mellitus tipo 2 (DM2) e hipertensão arterial sistêmica (HAS) podem contribuir para o desenvolvimento de doenças cardiovasculares, e os processos inflamatórios relacionados a estas doenças podem ser considerados importantes fatores para o prognóstico das mesmas. 0 objetivo deste estudo foi determinar os níveis plasmáticos de proteína Creativa ultra-sensível (us-PCR) em pacientes adultos com diabetes mellitus e/ou hipertensão arterial, comparando-os com indivíduos hígidos. Foram avaliadas 89 indivíduos, incluindo 13 pacientes normotensos com diabetes mellitus tipo 2 (DM2), 17 pacientes hipertensos (HAS), 34 pacientes hipertensos com diabetes mellitus tipo 2 (DM2+HAS) e 25 indivíduos hígidos. Os níveis plasmáticos de us-PCR foram significativamente mais altos no grupo DM2+HAS quando comparado com o grupo controle $(\mathrm{p}<$ 0,05 ), entretanto o mesmo não aconteceu com os grupos DM2 ou HAS. O grupo DM2+HAS também foi associado com o aumento dos níveis plasmáticos de us-PCR $(r=0,25 ; p<0,05)$ e apresentou a maior freqüência de us-PCR > 3,0 mg/L (59\%). Esses dados indicam que a presença combinada de diabetes mellitus tipo 2 e hipertensão arterial promoveu uma maior expressão do estado inflamatório, refletido pelos níveis plasmáticos de us-PCR nos indivíduos avaliados. (Arq Bras Endocrinol Metab 2007;51/6:956-960)

Descritores: Proteína C-reativa ultra-sensível; Diabetes mellitus tipo 2; Hipertensão arterial 
$\mathrm{T}^{\mathrm{N}}$

YPE 2 DIABETES MELLITUS (DM2) is an important public health problem worldwide because of its high prevalence and complications (1). The disease is characterized by metabolic alterations that correlate hyperglycaemia to other risk factors that contribute to complications in the circulatory system, such as high blood pressure (HBP) (2). The number of deaths related to DM2 represents $9 \%$ of the world total, with four million cases each year. Cardiovascular diseases (CVD) are the most prevalent cause of death in DM2 patients $(3,4)$, including myocardial infarction, ischaemic stroke, peripheral arterial obstructive disease and several other related diseases. Currently, atherosclerosis is indicated as the main cause for CVD development (5).

The main hypothesis for the origin of atherosclerosis considers it to be an inflammatory process that occurs in different forms, leading to vascular endothelium injury $(6,7)$. Chronic inflammatory processes favor clinical progression of atheroma plaques, which may suffer rupture and provoke thrombus formation and complications associated to atherosclerosis (8).

Based on multiple epidemiological and intervention studies, increased concentrations of high-sensitivity C-reactive protein (hs-CRP), a marker for systemic inflammation, are associated with future cardiovascular risk (hs-CRP $<1 \mathrm{mg} / \mathrm{L}=$ low risk, $1-3 \mathrm{mg} / \mathrm{L}=$ intermediate risk, $3-10 \mathrm{mg} / \mathrm{L}=$ high risk, $>10 \mathrm{mg} / \mathrm{L}=$ unspecific elevation) (9). Despite the fact that hs-CRP measurement may be useful for assessment of the risk of complications in diabetic patients (10), the ability of this marker to predict future risk of diabetes is still to be proven. However, a recent prospective study has shown that elevated hs-CRP levels may predict DM2 development among apparently healthy subjects (11). Also, there are only a few studies that have investigated the relationship between hs-CRP and hypertension, but these studies showed that hypertensive patients had higher hs-CRP levels than normotensive subjects $(12,13)$. Considering the hypothesis that DM2 and HBP may contribute for CVD development and that inflammation may be an important factor for these diseases, the present study aimed to measure plasma hs-CRP levels in subjects with type 2 diabetes mellitus and/or high blood pressure and compare them to normal subjects.

\section{MATERIALS AND METHODS}

\section{Subjects and study design}

Consecutive subjects were selected from the Santa Casa de Misericórdia Hospital, Belo Horizonte, MG, in this crosssectional cohort study. The approval by the ethical commit- tee was obtained from the Santa Casa de Misericórdia Hospital and Federal University of Minas Gerais Ethical Research Committee. Informed consent was sought from all participants. A total of 89 male and female subjects with an age range from 40 to 65 years were studied. Based on clinical and laboratory criteria, the participants were classified into four groups: normal subjects (control, $\mathrm{n}=25$ ), normotensive patients with type 2 diabetes mellitus (DM2, $\mathrm{n}=$ 13), patients with high blood pressure $(\mathrm{HBP}, \mathrm{n}=17)$ and hypertensive patients with type 2 diabetes mellitus $(\mathrm{HBP}+\mathrm{DM} 2, \mathrm{n}=34)$. Individuals were classified as having DM2 if plasma glucose were equal or superior to 126 $\mathrm{mg} / \mathrm{dL}$ in the fasting state (performed on all subjects not previously diagnosed as having diabetes) or if individuals were receiving oral anti-diabetic medicine or insulin (14). Hypertension was diagnosed if systolic or diastolic blood pressure exceeded 140 or $90 \mathrm{mmHg}$, respectively, or if the patient were using antihypertensive agents (15). All diabetic patients had their initial diagnoses up to 40 years of age. None, however, had recent episodes of ketoacidosis. Subjects with clinical or laboratory signs of liver or renal dysfunction, malignancy or a history of coagulation disorder were excluded from the study.

\section{Samples collection}

Fasting blood samples were obtained by venipuncture in the early morning. Five milliliters of blood was collected in a tube without anticoagulant (Becton-Dickinson). The samples were immediately centrifuged for 15 minutes at $1100 \mathrm{~g}$. The serum samples were immediately isolated, and the aliquots were stored at $-70^{\circ} \mathrm{C}$ for batch-wise analysis.

\section{hs-CRP assay}

Plasma hs-CRP levels were assessed using the C-Reactive Protein Turbidimetric Kit with specific high-sensitivity methodology (BioTécnica ${ }^{\circledR}$, Brazil) in a Cobas Mira Plus (Roche ${ }^{\circledR}$ ) device according to the manufacturer's instructions. In brief, the test samples were treated with a specific antibody to human CRP in a suitable buffer. The turbidity induced by the formation of immune complexes was measured at $546 \mathrm{~nm}$, and the values were then calculated automatically from a known standard. All the assay steps were performed automatically by the instrument. No significant cross-reactivity or interference from other biochemical parameters was observed for the assay (BioTécnica ${ }^{\circledR}$, Brazil). The lower limit of detection for the assay was $0.1 \mathrm{mg} / \mathrm{L}$. The intra- and inter-assay coefficients of variation were $1.87 \%$ and $1.90 \%$, respectively (BioTécnica ${ }^{\circledR}$, Brazil). A commercial control serum was used to verify the assay performance.

\section{Statistical analysis}

Data were analyzed by a Sigma Stat version 1.0 software system using the non-parametric Kruskal-Wallis test, followed by Dunn's multiple comparison test for hs-CRP levels. Since hsCRP values for high-risk CVD are well established $(3 \mathrm{mg} / \mathrm{L})$, frequencies for increased hs-CRP levels among patients and 
controls were compared by the exact Fisher test and the oddsratio was obtained. Spearman's correlation coefficient was used to measure the linear association between the presence of disease and plasma hs-CRP levels. The minimum size of the sample was defined using the coefficient of variation previously described in the literature, considering a ten percent variation about the average and a minimum number of eleven individuals per group. It was possible to verify statistical differences with a $5 \%$ level of significance.

\section{RESULTS}

The four groups studied presented homogeneity with respect to age; however, HAS and DM2+HAS groups showed a significantly higher body mass index (BMI) than the controls (table 1). The results for the plasma hs-CRP levels are shown as mean and standard deviation, and median and interquartile range in table 1 . The plasma hs-CRP levels were significantly lower in controls than in the HBP+DM2 group $(\mathrm{p}<0.05)$. However, no significant difference was seen in the plasma hs-CRP levels among the other groups. The distribution of plasma hs-CRP levels is shown in figure 1 .

DM2 allied to HBP was correlated with increased plasma hs-CRP levels $(\mathrm{n}=89, \mathrm{r}=0.25, \mathrm{p}=$ 0.0162 ). No correlation was observed for the isolated diseases. The prevalence of the hs-CRP $>3 \mathrm{mg} / \mathrm{L}$ in the groups studied is shown in table 2. Significant differences were observed $(p<0.05)$ when the number of patients with DM2+HBP $(\mathrm{n}=20)$ that presented increased hs-CRP levels $(>3 \mathrm{mg} / \mathrm{L})$ was compared with the number of control subjects $(\mathrm{n}=7)$.

\section{DISCUSSION}

Systemic hypertension and DM2 are well known as atherosclerosis risk factors, and arterial inflammation has emerged as central to the initiation and progression of atherosclerosis. In this study high plasma hs-CRP levels showed a positive and significant correlation with $\mathrm{DM} 2+\mathrm{HBP}$ cases $(\mathrm{r}=0.25, \mathrm{p}=0.02)$. However, no correlation was obtained for the isolated diseases.

A homogenous population was assessed with respect to age and showed that plasma hs-CRP levels were significantly higher in hypertensive patients with type 2 diabetes mellitus than in normal subjects (table 1). Low-grade inflammation occurs in diabetic patients as well as those with CVD (16). A possible mechanism by which DM2 might induce inflammation is by increasing advanced glycation end products that may activate macrophages and increase oxidative stress and interleukin- 6 synthesis, resulting in the production of CRP (10). The association of chronic lowgrade inflammation with the progress of atherosclerosis in patients with DM2 has not been confirmed. However, Wakabayashi \& Masuda showed that CRP levels were associated with arterial stiffness in patients with DM2 (17). Recent studies demonstrated associations between hypertension and increased hs-CRP plasma levels $(12,13)$. Chae et al. (18) suggested that HBP increases the risk of atherosclerosis by promoting inflammatory activation of the arterial wall. Hypertension may result in an increase in vascular oxidative stress and exert a pro-inflammatory influence on the arterial wall (13). However, the clear mechanism by which HBP leads to atherosclerosis remains unclear, and few studies have focused on the significance of elevated hs-CRP in hypertensive patients.

Another finding in this study was that hs-CRP levels did not correlate significantly with only one disease, i.e., DM2 or HBP. Despite the non-significant differences in hs-CRP levels in DM2 or HBP groups compared to normal subjects, the medians for the DM2 and HBP groups (table 1, figure 1) suggest that DM2 patients present a high risk for CVD development (hs-CRP > $3 \mathrm{mg} / \mathrm{L}$ ), and HBP patients present an intermediate risk for CVD (hs-CRP between 1-3

Table 1. Characterization of the studied groups according to sex, age and body mass index (BMI) expressed as mean and standard deviation and the hs-CRP assay results. Significant differences among the groups are represented by the letter $a$ vs. control $(p<0.05)$.

\begin{tabular}{|c|c|c|c|c|c|c|}
\hline & & Control & DM2 & HBP & DM2 + HBP & $p$ value \\
\hline$n(M / F)$ & & $25(8 / 17)$ & $13(6 / 7)$ & $17(5 / 12)$ & $34(9 / 25)$ & - \\
\hline Age (years) & & $52.4 \pm 5.9$ & $53.5 \pm 8.5$ & $54.9 \pm 5.9$ & $56.2 \pm 6.5$ & ns \\
\hline \multirow[t]{2}{*}{ BMI $\left(\mathrm{Kg} / \mathrm{m}^{2}\right)$} & & $25.2 \pm 3.9$ & $27.7 \pm 3.2$ & $28.2 \pm 3.6^{a}$ & $28.1 \pm 3.5^{a}$ & $\mathrm{p}^{\mathrm{a}}<0,05$ \\
\hline & Mean \pm SD & $2.34 \pm 1.70$ & $5.32 \pm 4.95$ & $3.54 \pm 2.99$ & $5.70 \pm 5.35^{a}$ & $\mathrm{p}^{\mathrm{a}}=0.016$ \\
\hline \multirow[t]{2}{*}{ hs-CRP (g/dl) } & Median & 1.70 & 3.20 & 2.50 & $3.50^{\mathrm{a}}$ & $\mathrm{p}^{\mathrm{a}}=0.004$ \\
\hline & Interquartile range & $1.17-3.38$ & $1.58-8.10$ & $1.38-4.48$ & $2.30-7.30$ & - \\
\hline
\end{tabular}

n: sample size, M: male, F: female, SD: standard deviation, DM2: type 2 diabetes mellitus, HBP: high blood pressure, hs-CRP: high-sensitivity C-reactive protein, ns: not significant. 


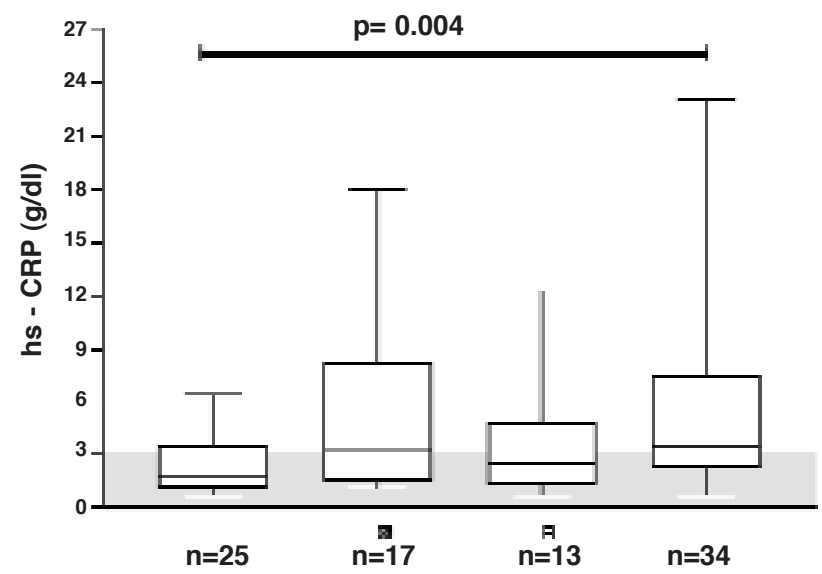

Figure 1. The distribution of high-sensitivity $\mathrm{C}$-reactive protein plasma levels in controls, DM2 (type 2 diabetes mellitus), HBP (high blood pressure) and DM2+HBP (both combined diseases). Each box represents the median and interquartile range with the minimum and maximum values. The shaded area corresponds to hs-CRP levels that represent low and intermediate risk for cardiovascular diseases $(<3 \mathrm{mg} / \mathrm{L})$.

Table 2. Odds ratios for type 2 diabetes mellitus (DM2), high blood pressure (HBP) and both diseases combined according to $>3 \mathrm{mg} / \mathrm{L}$ hs-CRP levels (high risk for cardiovascular diseases).

\begin{tabular}{lccccc}
\hline Groups & $\mathbf{n}$ & $\begin{array}{c}\text { hs-CPR }>\mathbf{3 . 0} \mathbf{~ g / d l} \\
\mathbf{n}(\mathbf{\%})\end{array}$ & $\begin{array}{c}\text { hs-CPR }<\mathbf{3 . 0} \mathbf{~ g / d l} \\
\mathbf{n}(\mathbf{\%})\end{array}$ & $\begin{array}{c}\text { Odds Ratio } \\
\text { (95\% confidence interval) }\end{array}$ & $\boldsymbol{p}$ value \\
Control & 25 & $18(72)$ & $7(28)$ & - & - \\
DM2 & 13 & $6(46)$ & $7(54)$ & $3.08(0.77-11.76)$ & $\mathrm{p}=0.163$ \\
HBP & 17 & $10(59)$ & $7(41)$ & $1.84(0.51-6.44)$ & $\mathrm{p}=0.508$ \\
DM2+HBP & 34 & $14(41)$ & $20(59)$ & $3.67(1.23-10.91)$ & $\mathrm{p}=0.034$ \\
\hline
\end{tabular}

DM2: type 2 diabetes mellitus, HBP: high blood pressure, hs-CRP: high-sensitivity C-reactive protein.

$\mathrm{mg} / \mathrm{l})(9)$. There was also no difference in plasma hsCRP levels between the DM2 and HBP groups.

In the present study, $59 \%$ of the patients with both hypertension and diabetes mellitus presented hsCRP levels superior to $3 \mathrm{mg} / \mathrm{L}$ (table 2), a level that is significantly different from the control group (OR 3.67, IC 1.23-10.91). However, patients with either DM2 or HBP separately did not present significant differences compared to controls for the marker hsCRP $>3 \mathrm{mg} / \mathrm{L}$. These data suggest a concomitant action of these two diseases (DM2+HBP) in the occurrence of an increase in the inflammatory process that is reflected by an increase in hs-CRP levels. Liu et al. (19) reported increased hs-CRP levels in apparently healthy women with a dietary glycemic load, thus showing a strong positive association, independent of conventional risk factors. Meanwhile, Bener et al. (20) demonstrated a strong association between HBP and glucose levels when comparing a large number of DM2 patients and normal subjects. Pro-inflammatory process exacerbation may be a mechanism whereby high glucose levels in association with HBP increases the risk of cardiovascular diseases. The characterization of these factors will contribute to defining more effective and specific strategies for treatment of these diseases.

In conclusion, hypertensive patients with type 2 diabetes mellitus, but not those with either hypertension or type 2 diabetes mellitus, were observed to have higher levels of hs-CRP, a circulating inflammatory marker, than normal subjects. This finding suggests that patients with two associated diseases have a more active inflammatory state.

\section{ACKNOWLEDGEMENTS}

We are very grateful to CAPES, CNPq and FAPEMIG for financial support. We also thank Laboratel Laboratório de Análises Clínicas for technical support. 


\section{REFERENCES}

1. Lyra R, Oliveira M, Lins D, Cavalcanti N. Prevention of type 2 diabetes mellitus. Arq Bras Endocrinol Metab 2006;50(2):239-49.

2. Davidson MB. Diabetes mellitus: Diagnóstico e Tratamento. $4^{a}$ ed. Rio de Janeiro: Revinter, 2001.

3. Ferreira SRG, Almeida B, Siqueira AFA, Khawali C. Interventions on the prevention of type 2 diabetes mellitus: is it feasible a population-based program in our country? Arq Bras Endocrinol Metab 2005;49(4):479-84.

4. Zimmet P, Albert KGMM, Shaw J. Global and societal implications of the diabetes epidemic. Nature 2001;414:782-7.

5. WHO (World Health Organization). Health topics. Disponível em: <http://www.who.int/cardiovascular_diseases/ em/>. 2004. Acessado em: Março de 2006

6. Ross R. Mechanisms of disease: atherosclerosis an inflammatory disease. N Eng J Med 1999;340:115-26.

7. Libby $P$, Ridker PM, Maseri A. Inflammation and atherosclerosis. Circulation 2002;105:1135-43.

8. Garcia-Palmieri MR. The endothelium in health and in cardiovascular disease. P R Health Sci J 1997;16:136-41.

9. Pfutzner A, Forst T. High-sensitivity C-reactive protein as cardiovascular risk marker in patients with diabetes mellitus. Diabetes Technol Ther 2006;8(1):28-36.

10. Mankowska A, Pollak J, Sypniewska G. Association of C-reactive protein and other markers of inflammation with risk of complications in diabetic subjects. Disponível em: <http://www.ifcc.org/ejifcc/vol17no1/17010320063.htm >. Acessado em: Março de 2006.

11. Prasad K. C-reactive protein and cardiovascular diseases. IntI Angiol 2003;12:1-12.

12. Bautista LE, Lopez-Jaramillo P, Vera LM, Casas JP, Otero AP Guaracao Al. Is C-reactive protein an independent risk factor for essential hypertension? J Hypertens 2001;19:857-61.

13. Choi H, Cho DH, Shin HH, Park JB. Association of high sensitivity C-reactive protein with coronary heart disease prediction, but not with carotid atherosclerosis, in patients with hypertension. Circ J 2004;68:297-303.
14. ADA (American Diabetes Association). Follow-up report on the diagnosis of diabetes mellitus. Diabetes Care 2003;26.

15. Chobanian AV, Bakris GL, Black HR, Cushman WC, Green LA, Izzo Jr JL, et al. National High Blood Pressure Education Program Coordinating Committee. The seventh report of the Joint National Committee on prevention, detection, evaluation, and treatment of high blood pressure: The JNC 7 report. JAMA 2003;289:2560-72.

16. Nakamura A, Shikata $K$, Hiramatsu M, Nakatou $T$, Kitamura $T$, Wada J, et al. Serum interleukin-18 levels are associated with nephropathy and atherosclerosis in Japanese patients with type 2 diabetes. Diabetes Care 2005;28:2890-5.

17. Wakabayashi I, Masuda H. Association of acute-phase reactants with arterial stiffness in patients with type 2 diabetes mellitus. Clin Chim Acta 2006;365(1-2):230-5.

18. Chae CU, Lee RT, Rifai N, Ridker PM. Blood pressure and inflammation in apparently healthy men. Hypertension 2001;38:399-403.

19. Liu S, Manson JE, Buring JE, Stampfer MJ, Willett WC, Ridker PM. Relation between a diet with a high glycemic load and plasma concentrations of high-sensitivity C-reactive protein in middle-aged women. Am J Clin Nutr 2002;75:492-8.

20. Bener A, Zirie M, Al-Rikabi A. Genetics, obesity, and environmental risk factors associated with type 2 diabetes. Croat Med J 2005;46(2):302-7.

Endereço para correspondência:

Marinez Oliveira Sousa

Faculdade de Farmácia

Universidade Federal de Minas Gerais

Av. Antônio Carlos 6627

$31270-901$ Belo Horizonte, MG

Fax: (31) 3499-6985

E-mail: marinez@farmacia.ufmg.br 